\title{
No impact of $B t$ soybean that express Cry1Ac protein on biological traits of Euschistus heros (Hemiptera, Pentatomidae) and its egg parasitoid Telenomus podisi (Hymenoptera, Platygastridae)
}

\author{
Gabriela Vieira Silva ${ }^{1}$, Amarildo Pasini², Adeney de Freitas Bueno ${ }^{3}$, Orcial Ceolin Bortolotto ${ }^{1}$, \\ Gustavo Caselato Barbosa ${ }^{4} \&$ Ynaiara Kristhine Stopa Cruz ${ }^{5}$
}

\footnotetext{
${ }^{1,4}$ Departamento de Zoologia, Setor de Ciências Biológicas, Universidade Federal do Paraná, Av. Cel. Francisco H. dos Santos, 210, Jardim das Américas, 81531-970 Curitiba-PR, Brasil.gabriela1vieirasilva@gmail.com; bortolotto.orcial@gmail.com

${ }^{2}$ Departamento de Agronomia, Centro de Ciências Agrárias, Universidade Estadual de Londrina, Caixa Postal 10011 Rodovia Célso García Cid, Km 380 - Campus Universitário, 86057-970, Londrina-PR, Brasil. pasini@uel.br

${ }^{3}$ Embrapa Soja, Laboratório de Parasitoides, Rodovia Carlos João Strass - Distrito de Warta, Caixa Postal 231, 86001-970, Londrina-PR, Brasil. adeney.bueno@embrapa.com.br

${ }^{4}$ Centro Universitário Filadélfia, Rua Alagoas, 2050, 86020-430, Londrina-PR, Brasil. agrogustavo2015@hotmail.com

${ }^{5}$ Universidade Estadual do Norte do Paraná, Campus Cornélio Procópio; PR 160, Km 0, 863000-000, Cornélio Procópio-PR, Brasil. yna.kris@hotmail.com
}

\begin{abstract}
No impact of Bt soybean that express CrylAc protein on biological traits of Euschistus heros (Hemiptera, Pentatomidae) and its egg parasitoid Telenomus podisi (Hymenoptera, Platygastridae). Biological traits of the stink bug Euschistus heros and its main biological control agent Telenomus podisi were evaluated under controlled environmental conditions $(25 \pm$ $2^{\circ} \mathrm{C} ; 60 \pm 10 \% \mathrm{RH}$; and 14/10 h photoperiod) by placing first instar nymphs into Petri dishes with pods originating from two soybean isolines $(B t$-soybean MON $87701 \times$ MON 89788, which expresses the Cry1Ac protein, and its near non- $B t$ isoline A5547) where they remained until the adult stage. Due to gregarious behavior exhibited by first instar nymphs, they were individualized only when at the second instar. Adults were separated by sex and weighed, and pronotum width of each individual was subsequently measured. They were placed into plastic boxes containing soybean grains of the same soybean isoline as food source. Egg viability and female fecundity were assessed in adult individuals. Adult females of $T$. podisi (up to 24h old) were placed with eggs of $E$. heros from mothers reared on both soybean isolines. Nymphal development time, insect weight, pronotum width, sex ratio, female fecundity, and egg viability (\% emergence) of Euschistus heros did not differ between treatments. Eggto-adult development time, female longevity, sex ratio, and percentage of parasitized eggs were not impacted by the $B t$-soybean (expressing Cry1Ac protein). Results indicate that the Bt-soybean, MON $87701 \times$ MON 89788, has no direct significant impact on the two studied species.
\end{abstract}

KEYWORDS. Egg parasitoid; genetically modified organisms (GMO); natural enemy; non-target pests; plant resistance.

Soybean [Glycine max (L.) Merrill] is an oilseed plant of the family Fabaceae which is widely cropped in various countries worldwide (Roese et al. 2001). Caterpillars and stink bugs are the key pests responsible for the main yield loss of this crop (Gamundi \& Sosa 2008). Among these pests, Euschistus heros (Fabricius, 1794) (Hemiptera, Pentatomidae) stands out as the most common and important stink bug that damages soybean pods in Brazil and other soybean growing areas in South America. Moreover, E. heros is the most difficult pest species to be controlled, due to its proven resistance to different insecticides (Sosa-Gomez \& Silva 2010; Saluso et al. 2011).

The cultivation of genetically modified plants (e.g. Btsoybean) is currently an alternative method of controlling major crops pests. The $B t$-soybean plants contain the cry gene, which codes for the toxic protein Cry1Ac derived from the bacterium Bacillus thuringiensis Berliner. This protein causes a reduction of feeding, and consequently the inhibition of caterpillar development by specific binding in the ciliated membranes of the medium intestine, leading to increased mortality rates of pest-insects of the order Lepidoptera (Yu et al. 2011). Bt-corn, as well as Bt-cotton, which also contain cry genes, efficiently controlled major pests that affect these crops and led to an increase of production and insecticide reduction (Gonzales-Nunez et al. 2000; Pray et al. 2002; Sanvido et al. 2009). Insect control by Bt-soybean has been particularly effective for the species Chrysodeixis includens (Walker, 1857) (Lepidoptera, Noctuidae) and Anticarsia gemmatalis (Hübner, 1818) (Lepidoptera, Erebidae) (Bernardi et al. 2012). However, since this is a novel technology, further information on $B t$-soybean impact on this agroecosystem is still needed.

Besides knowing the effects of $B t$-soybean on target-organisms (Bernardi et al. 2012; Homrich et al. 2008), it is also important to study their effects on non-target pests and natural enemies, since these insects may be directly or indirectly exposed to $B t$ toxin for long time periods (Andow \& Hilbeck 2004). Moreover, Bt-plants provide effective con- 
trol of many pest-insects and lead to reduced insecticide use (Sharma \&Ortiz 2000; Wu 2001; Sisterson et al. 2007; Kouser $\&$ Quaim 2011) thereby decreasing production costs and preserving biological control agents. In addition, they minimize the impact of toxic chemicals to humans, animals, and the environment (Loguercio et al. 2001). However, the use of transgenic plants (GMOs), and the resulting reduction of insecticides against target pests may allow other pest species to become more relevant in agricultural environments $(\mathrm{Wu}$ et al. 2005). Therefore, research on the interaction of nontarget species (non-target pests and natural enemies) with this new $B t$ technology is of great theoretical and practical importance.

Both the stink bug E. heros, and its natural egg parasitoid Telenomus podisi Ashmead, 1893 (Hymenoptera, Platygastridae) can be directly or indirectly affected by the Cry1Ac toxic protein on $B t$-soybean plants. The egg parasitoid $T$. podisi is common and has high potential to control eggs of E. heros (Laumann et al. 2009). However, the success of its parasitism, which may reach $83 \%$ under natural conditions, depends on different factors such as its ability to search for host eggs, parasitism capacity, and parasitism viability among others (Pacheco \& Corrêa-Ferreira 2000). Therefore, this study aimed at evaluating possible direct or indirect effects of the adoption of MON $87701 \times$ MON 89788 on the insectpest $E$. heros, as well as on its egg parasitoid T. podisi, to improve understanding of the tritrophic interaction $B t$-soybean/pest/natural enemy.

\section{MATERIAL AND METHODS}

Experimental conditions and organisms. In a BOD environmental control chamber [temperature $25 \pm 2^{\circ} \mathrm{C}$, relative humidity (RH) $60 \pm 10 \%$, photoperiod 14/10 L:D], two bioassays were carried out: a) biological traits of the stink bug $E$. heros fed with non-Bt and Bt-soybean MON $87701 \times$ MON 89788, and b) biological traits of the parasitoid T. podisi developing in eggs of E. heros fed with non-Bt and Bt-soybean MON $87701 \times$ MON 89788. Adults and eggs of $E$. heros were obtained from the laboratory of Embrapa Soybean, where this insect is mass-reared for many successive generations per year. The parasitoid T. podisi was also obtained from the Embrapa Soybean laboratory, where this insect has been reared in egg masses of $E$. heros for five years under controlled environmental conditions $\left(25 \pm 2{ }^{\circ} \mathrm{C}\right.$, RH $60 \pm 10 \%$, 14/10 h L/D photoperiod).

Soybean cultivars used in this study were developed by the Monsanto Company. Two soybean isolines, derived from the same cross were used: the $B t$-soybean MON $87701 \times$ MON 89788 expressing the Cry1 Ac toxic protein and its non- $B t$ isoline A5547. Seeds of both genotypes were sown into plastic pots ( 8 liter capacity each) filled with sterilized soil and subsequently maintained in a greenhouse $\left(25 \pm 2{ }^{\circ} \mathrm{C}\right.$, RH $60 \pm$ $10 \%, 14 / 10 \mathrm{~h} \mathrm{~L} / \mathrm{D}$ photoperiod). Each pot for each soybean isoline ( $B t$ and non- $B t$ ) contained five seeds. A sulfur-based fungicide $\left(\right.$ Kumulus $^{\circledR}$ ) with a dosage of 0.5 g. $1^{-1}$ was applied weekly against soybean powdery mildew (Microsphaera diffusa Cke. \& Pk.). Plants that reached the vegetative growth stage $V_{2}$ (Fehr \& Caviness 1977) were fertilized with a formulation of 0-20-20 (NPK). Soil humidity of each pot was monitored daily, and provided with drip irrigation whenever needed.

After plants had reached the reproductive stage $\mathrm{R}_{6}$ (full seed) (Fehr \& Caviness 1977), pods were collected to feed the stink bugs. Before offering them to insects, pods were treated by immersing them in a 5\% sodium hypochlorite solution for $15 \mathrm{~min}$ and then dried for $2 \mathrm{~h}$, to allow evaporation of the solution.

Biological traits of $E$. heros fed with $B t$-soybean MON $87701 \times$ MON 89788 and its non-Bt isoline A5547. The trial was carried out in a completely randomized experimental design with two treatments ( $B t$-soybean MON $87701 \times$ MON 89788 and its non-Bt isoline A5547) and eight replicates with eight nymphs each replication, which were individualized into Petri dishes $(6 \mathrm{~cm} \varnothing)$ lined with filter paper. Individualization of nymphs was performed at second instar. At the first instar there is no need for individualization since nymphs do not feed besides showing a gregarious behavior. Due to this gregarious behavior individualization could increase mortality at the first instar and was therefore avoided. To feed the insects, each Petri dish was provided with a soybean pod of each genotype ( $B t$ soybean and non- $B t$ soybean) as well as a small plastic tube containing water that was topped with a cotton plug.

Within a 24-h interval after the last ecdysis, each adult stink bug was weighed using an analytical balance with a precision of $0.001 \mathrm{~g}$, sexed, and subsequently photographed to measure pronotum width $(\mathrm{mm})$ with the software Leica Application Suite 1.6.0. Stink bugs were then paired and placed into transparent plastic boxes $\left(\mathrm{Gerbox}^{\circledR}\right.$ boxes, $11 \mathrm{~cm}$ $\times 11 \mathrm{~cm} \times 3.5 \mathrm{~cm}$ ) with perforated lids to allow circulation of air and lined with filter paper. To feed the insects, a small plastic tube containing water topped with a cotton plug was placed in each box. Filter paper, water, and soybean pods were offered daily.

Mortality and duration of nymphal pest stage were recorded. For adults, weight, pronotum width, sex ratio, and viability of eggs were evaluated. To assess viability of eggs, the egg masses laid by the pest species were transferred to Petri dishes $(6 \mathrm{~cm} \varnothing)$ and kept in the same environmental conditions (temperature, humidity, and photoperiod) as the adult insects until the eclosion of nymphs. After hatching, nymphs were counted to allow for computation of egg viability.

Biological traits of $T$. podisi developing in eggs of $E$. heros fed with $B t$-soybean MON $87701 \times$ MON 89788 and its non-Bt isoline A5547. E. heros eggs used to study the biology of $T$. podisi were reared in plastic boxes with dimensions of 25 $\times 30 \times 30 \mathrm{~cm}$. Eggs collected in the boxes had been stored in a liquid nitrogen chamber $\left(-196^{\circ} \mathrm{C}\right)$, which does not affect the quality of eggs of this insect-pest, even when stored for a 360day period (Corrêa-Ferreira \& Oliveira 1998). Egg collection was performed over a period of 60 days in order to obtain a sufficient amount of eggs for the study. 
Twenty-five $E$. heros eggs were fixed with non-toxic glue to a small rectangular card of white Bristol paper $(0.8 \mathrm{~cm} \times 5$ $\mathrm{cm})$ and placed into a Duran glass tube $(1 \mathrm{~cm} \varnothing \times 6 \mathrm{~cm}$ tall $)$ for each replicate. Immediately after that, a newly-hatched female of $T$. podisi, between 24 and $48 \mathrm{~h}$ old and previously mated was introduced to the tube together with a droplet of honey to feed the parasitoid, and sealed with plastic film. Parasitism was allowed for $24 \mathrm{~h}$. After this period, the cards with the parasitized eggs were removed and separately transferred to glass tubes $(2 \mathrm{~cm} \varnothing \times 8 \mathrm{~cm}$ tall $)$ until the emergence of adults. The parental females remained in the same environmental chamber to assess their longevity. The experiment was carried out in a completely randomized experimental design with 35 replications. Each replicate was represented by a group of E. heros eggs (twenty five eggs) and a parasitoid female individualized into each glass tube. The parameters assessed were: longevity of parental females, egg-adult period, viability and percentage of parasitism, emergence percentage, and sex ratio.

Statistical analysis. Results obtained from bioassays were subjected to exploratory analyses to assess the assumptions of normality of residuals (Shapiro \& Wilk 1965), homogeneity of variance of treatments and additivity of the model (Burr \& Foster 1972) prior to ANOVA. Means were then compared by Student's t test $(p \leqslant 0.05)$ (SAS Institute 2001).

\section{RESULTS}

Development time and survival (\%) of E. heros nymphal stages, as well as weight, pronotum size, sex ratio and fecundity of adults, and egg viability did not differ between $B t$ and non- $B t$ treatments (Table I). Similarly, the $B t$-soybean MON $87701 \times$ MON 89788 had no impact on development of the egg parasitoid T. podisi. Overall, percentage and viability of parasitism, egg-adult period, sex ratio and longevity of parental females of $T$. podisi did not differ between treatments (Table II).

\section{DISCUSSION}

Our results suggest that the adoption of $B t$-soybean MON $87701 \times$ MON 89788 will not directly affect the population density of the stink bug E. heros in the field given that the development of the stink bug was not impaired by this soybean cultivar under laboratory controlled environmental conditions. Because the biological parameters assessed did not differ between the two treatments, it appears that both tested soybeans provided the same nutritional quality for the stink bug development.

Lower nutritional quality or the presence of antibiotics or other toxins unfavorable for development will increase the developmental time of nymphs of the stink bug E. heros and thus the time to reach the critical weight that triggers the molting process (Panizzi \& Parra 1991). However, nymphal development time did not differ between the groups fed on $B t$-soybean (expressing Cry1Ac protein) and its non- $B t$ isoline. Moreover, nymphal development time in our study ( $23.53 \pm 0.18$ days) was similar to previously published results, where nymphs of E. heros were reared at $26^{\circ} \mathrm{C}$, and fed with a mixture of soybean and peanuts seeds $(23.05 \pm 0.19$ days) (Cividanes \& Parra 1994). Such non-interference of $B t$ soybean with the E. heros biology was confirmed by the

Table I. Biological parameters (means \pm SEM) assessed for nymphs and adults of the stink bug Euschistus heros (Fab.) fed with Bt and non-Bt soybean.

\begin{tabular}{|c|c|c|c|c|c|c|c|}
\hline \multirow{3}{*}{ Origin of pods } & \multicolumn{7}{|c|}{ Parameters assessed } \\
\hline & \multicolumn{2}{|l|}{ Nymph } & \multicolumn{5}{|c|}{ Adult } \\
\hline & Development time (days) ${ }^{1}$ & Survival (\%) & Weight $(\mathrm{g})^{1}$ & Pronotum size $(\mathrm{mm})^{1}$ & Sex ratio $^{1}$ & Fecundity ${ }^{1}$ & Egg viability ${ }^{1}$ \\
\hline Bt soybean & $23.15 \pm 0.16^{\mathrm{ns}}$ & $82.65 \pm 0.69^{\text {ns }}$ & $0.0725 \pm 0.0021^{\mathrm{ns}}$ & $8.25 \pm 0.08^{\text {ns }}$ & $0.7375 \pm 0.0952$ & $166.44 \pm 24.62$ & $68.57 \pm 0.05$ \\
\hline Non- $B t$ soybean & $23.39 \pm 0.19$ & $83.19 \pm 0.71^{\mathrm{ns}}$ & $0.0721 \pm 0.001$ & $8.07 \pm 0.22$ & $0.5675 \pm 0.1372^{\mathrm{ns}}$ & $200.00 \pm 17.62^{\mathrm{ns}}$ & $75.97 \pm 0.05^{\mathrm{ns}}$ \\
\hline $\mathrm{CV}(\%)$ & 1.51 & 8.04 & 4.05 & 4.13 & 20.56 & 14.00 & 9.06 \\
\hline $\mathrm{DF}_{\text {residuals }}$ & 6 & 7 & 6 & 6 & 6 & 10 & 5 \\
\hline $\mathrm{F}$ & 0.93 & 7.06 & 0.03 & 0.62 & 1.11 & 4.96 & 5.32 \\
\hline $\mathrm{p}$ & 0.3723 & 0.5196 & 0.8676 & 0.4614 & 0.3336 & 0.5254 & 0.4356 \\
\hline
\end{tabular}

${ }^{1}$ Means \pm SEM followed by the same letter in the columns do not statistically differ between each other $(t$-test, $\mathrm{p} \geqslant 0.05) ; \mathrm{ns}=$ non-significant; $\mathrm{DF}_{\text {residuals }}=$ degrees of freedom of residuals; $\mathrm{F}$ = statistics F.

Table II. Biological parameters (means \pm SEM) of Telenomus podisi parasitoids on Euschistus heros eggs from Bt and non-Bt soybean.

\begin{tabular}{|c|c|c|c|c|c|}
\hline \multirow{2}{*}{ Origin of pods } & \multicolumn{5}{|c|}{ Assessed parameters ${ }^{1}$} \\
\hline & Longevity of parental females (days) & Egg-adult period (days) & Parasitism (\%) & Parasitism viability (\%) & Sex ratio \\
\hline Bt soybean & $16.46 \pm 0.47^{\mathrm{ns}}$ & $15.2 \pm 0.31^{\mathrm{ns}}$ & $19.13 \pm 2.80^{\mathrm{ns}}$ & $73.08 \pm 4.70^{\mathrm{ns}}$ & $0.65 \pm 0.10^{\text {ns }}$ \\
\hline Non- $B t$ soybean & $19.66 \pm 0.43^{\mathrm{ns}}$ & $15.07 \pm 0.26$ & $24.99 \pm 2.40$ & $81.03 \pm 3.30$ & $0.73 \pm 0.04$ \\
\hline CV (\%) & 14.18 & 5.11 & 31.33 & 14.00 & 28.48 \\
\hline $\mathrm{DF}_{\text {residuals }}$ & 12 & 12 & 12 & 12 & 12 \\
\hline $\mathrm{F}$ & 5.31 & 0.10 & 2.52 & 1.09 & 0.62 \\
\hline $\mathrm{p}$ & 0.2345 & 0.7533 & 0.1385 & 0.1936 & 0.4446 \\
\hline
\end{tabular}

${ }^{1}$ Means \pm SEM followed by the same letter in a column of the same insect developmental stage do not differ statistically between each other (t-test, $\left.\mathrm{p} \leqslant 0.05\right)$; ns $=$ nonsignificant; $\mathrm{DF}_{\text {residuals }}=$ degrees of freedom of residuals; $\mathrm{F}=$ statistics $\mathrm{F}$. 
weight of adults, which was similar in both treatments. Generally, the fifth nymphal instar of stink bugs is most susceptible to a change in the nutritional quality of food (Panizzi \& Rossini 1987). During this stage, several physiological and morphological changes occur, especially in form and biological structure, with an intense biochemical activity that involves essential enzymes and hormones transforming nymphs into adults (Panizzi \& Parra 1991).

Numbers of eggs per female did not differ between treatments with MON $87701 \times$ MON 89788 soybean (166.4 eggs/ female) and its non- $B t$ isoline A5547 (200 eggs/female), with values slightly lower than previously reported (293.7 eggs/female) (Cividanes \& Parra 1994). The lower number of eggs per female recorded here may be due to peanuts added to the food used in previous studies conducted by Cividanes \& Parra (1994), which are known to increase insect fertility (Siqueira 2007).

Sex ratio and nymphal survival in our study were similar to previously reported results by Cividanes \& Parra (1994), confirming no interference of the $B t$-soybean MON $87701 \times$ MON 89788 with the biology of this insect species. In addition to chemical food characteristics, physical characteristics of the external surface of pods (such as the pilosity), or the distance between seed and inner wall of the pod may inhibit successful feeding of younger nymphs and lead to their premature death (Panizzi and Parra 1991).

Differing results in the literature regarding the direct impact of Bt-plants on non-target insects (pests and their natural enemies) emphasize the importance of our study on biological aspects of $E$. heros fed with $B t$ and non- $B t$ soybeans. In a study performed in China, similar results for Apolygus lucorum (Meyer-Dür, 1843) (Hemiptera, Miridae) were obtained with this stink bug feeding on $B t$ plant also expressing Cry1Ac protein (Bt cotton) (Li et al. 2011). Authors showed no statistical differences for survival and fecundity and other biological parameters of Aphis gossypii (Glover, 1877) (Hemiptera, Aphididae) on Bt (expressing Cry1Ac protein) and non-Bt cotton. These authors concluded that the occurrence of this pest in the field is unrelated to $B t$ crop cultivation. On the other hand, wingless and winged aphids showed an improved development on Bt cotton (expressing Cry1Ac protein) compared to individuals on non$B t$ cotton (Fernandes et al. 2012). A possible explanation for this difference is that $B t$ cotton (expressing Cry1Ac protein) plants may produce a lower amount of amino acids and sugars, making them less attractive to herbivorous insects (Yan et al. 2007). Another important aspect of the possible interference of $B t$ plants with the development of non-target insects is the amount of the Cry toxic protein expressed at the pest feeding spot on the plant, as many pests species of the order Hemiptera predominantly feed on photosynthetically produced sap on leaves passing through the phloem (Douglas 2003). These insects ingest only the amount of toxic Cry proteins transported through such structures to other parts of the plant (Romeis \& Meissle 2011).

In addition to its direct effects on the soybean entomofauna, $B t$ technology may also have indirect effects on insect pests and their natural enemies (Xia et al. 1999). Expectations are that with increasing $B t$-soybean cultivation, less insecticide spraying is required. For example in China, insecticides on Bt-cotton (expressing Cry1Ac protein) were already reduced by $60 \%$ to $80 \%$ (Xia et al. 1999), and by $27 \%$ to $61 \%$ in the USA (Bobrowski 2003). Control of key caterpillar-pests such as $C$. includens and $A$. gemmatalis by $B t$ technology (expressing Cry1Ac protein) may eventually reduce insecticide use on soybean crop as well. On one hand, a reduction of insecticides may favor the occurrence of the stink bug E. heros, whose populations are affected by insecticides used to control caterpillars and on the other hand may help to preserve natural biological control. In China, populations of the natural enemy of insect-pests in fields with non- $B t$ cotton increased by $24 \%$, compared to a field where insect-pests were controlled using conventional chemical treatment (Xia et al. 1999). Such results emphasize the need of assessing the impact of $B t$ technology on the non-target pests already existing in the agro-ecosystem. To this end, it was suggested to assess the effects and ecotoxicological risks of the toxic Cry1Ac protein on the biology of natural enemies by using insect-pests resistant to this protein (Frizzas \& Oliveira 2006).

Our study suggests that the ability of the egg parasitoid $T$. podisi to control the stink bug E. heros was not altered in areas cultivated with $B t$-soybean MON $87701 \times$ MON 89788, with similar parasitism capacity and viability of parasitized eggs under both treatments. Analogous results were found e.g. for egg masses of Ostrinia nubilalis (Hübner, 1796) (Lepidoptera, Crambidae) parasitized by the parasitoids Eriborus terebrans (Gravenhorst, 1829) (Hymenoptera, Ichneumonidae) and Macrocentrus grandii Goidanich 1937 (Hymenoptera, Braconidae), where the percentage of parasitism was unaffected in areas cultivated with transgenic maize expressing Cry1 Ab protein (Orr \& Landis 1997). Survival and development of the stink bug predator Orius insidiosus (Say, 1832) (Hemiptera, Anthocoridae), another non-target species, were not affected when exposed to protein Cry3Bb1 provided by an artificial diet (Duan et al. 2008).

Parasitoid sex ratio is a biological feature that may be influenced by the nutritional quality of the plant on which the pest (host species) fed during development (Vinson 1997). It was proven that host quality is the major feature affecting sex ratio of egg parasitoids of Trichogramma spp. (Vinson 1997), another egg parasitoid species. This may occur due to the ability of females to determine the most suitable host species for generating new males or females by the nutritional quality of the host eggs. Moreover, sex ratio may likewise be related to the survivability of parasitoid males or females within the egg (Vinson 1997). Under field conditions, other factors such as possible beneficial or deleterious effects of a new agricultural system on natural biological control of insect-pests should also be considered. It is known that egg parasitoids are able to distinguish different substances related to the presence of a host, especially the chemical substances exhaled by the insect-pest eggs of their preference 
(Wackers \& Lewis 1994; Larsson \& Svensson 2004). Telenomus podisi uses mainly male pheromones to locate eggs of E. heros (Silva et al. 2006). It is still unclear whether ingestion of toxic proteins present in $B t$ soybean affects the production of volatile substances released by the pest, which could interfere with the search for host eggs by parasitoids. In addition, the tritrophic relation of plant/pest/parasitoid must be considered. Other studies have shown that the egg parasitoid T. podisi prefers plants damaged by E. heros to healthy plants (Lopes et al. 2012) which emphasizes the need for further experiments with $B t$-plants under field conditions in order to clarify this relationship. However, since no adverse impact of $B t$ soybean above $T$. podisi sex ratio was observed in our study, these results suggest that $E$. heros egg is nutritionally and chemically similar to the eggs originated from stink bugs which fed on both $B t$ and non-Bt soybean pods.

Therefore, since there was no impact of MON $87701 \times$ MON 89788 soybean on E. heros, population growth of this pest species may be possible under field conditions when insecticide use is reduced, as already observed in China, Australia, USA, South Africa and India (Sharma \& Ortiz 2000; Wu 2001; Li et al. 2011; Wilson et al. 2006; Williams 2006; Gouse et al. 2004; Lu et al. 2010) for the species $A$. lucorum on $B t$ cotton (expressing Cry1Ac protein). On the other hand since no adverse effect was observed on the egg parasitoid T. podisi, even in such a scenario, biological control by the parasitoids $T$. podisi may help to control E. heros populations in areas with the $B t$-soybean $\mathrm{MON} 87701 \times \mathrm{MON}$ 89788. The parasitoid T. podisi could reduce the need for insecticide application to control stink bugs and therefore have a positive effect on the evolutionary rate of insecticide resistance (Chilcutt \& Tabashnik 1999) frequently observed in populations of $E$. heros on soybeans in Brazil (Sosa-Gómez \& Silva 2010; Saluso et al. 2011).

In summary, the results of this study suggest that there is no direct effect of MON $87701 \times$ MON 89788 soybean on biological traits of $E$. heros or its egg parasitoid T. podisi. However, indirect effects of the $B t$ technology still need to be examined under field conditions in larger areas.

\section{ACKNOWLEDGMENTS}

Authors wish to thank Embrapa Soybean, the sponsor agencies CAPES, CNPq and FAPESP for financial support; and to Monsanto Brazil Ltda for the seeds provided to accomplish this study and to Dagmar Frisch for English revision.

\section{REFERENCES}

Andow, D.A. \& Hilbeck, A. 2004. Science-based risk assessment for nontarget effects of transgenic crops. BioScience 54: 637-649.

Bernardi, O., Malvestiti, G.S., Dourado, P.M., Oliveira, W.S., Martinelli, S., Berger, G.U., Head, G.P. \& Omoto, C. 2012. Assessment of the high - dose concept and level of control provided by MON $87701 \times$ MON 89788 soybean against Anticarsia gemmatalis and Pseudoplusia includens (Lepidoptera: Noctuidae) in Brazil. Pest Management Science 68: 1083-1091.
Bobrowski, V.L., Fiuza, L.M., Pasquali, G. \& Bodanese-Zanettini, M.H. 2003. Genes de Bacillus thuringiensis: uma estratégia para conferir resistência a insetos em plantas. Ciência Rural 34: 843-850.

Burr, I.W. \& Foster, L.A. 1972. A test for equality of variances. Mimeo Series no. 282. West Lafayette, University of Purdue, 26 p.

Chilcutt, C.F. \& Tabashnik, B.E. 1999. Simulation of integration of Bacillus thuringiensis and the parasitoid Cotesia plutellae (Hymenoptera: Braconidae) for control of suceptible and resistant diamondback moth (Lepidoptera: Plutellidae). Environmental Entomology 28: 505-512.

Cividanes, F.J. \& Parra, J.R.P. 1994. Biologia em diferentes temperaturas e exigências térmicas de percevejos pragas da soja. II. Euschistus heros (Fabr.) (Heteroptera: Pentatomidae). Pesquisa Agropecuária Brasileira 29: 1841-1846.

Corrêa-Ferreira, B.S. \& Oliveira, M.C.N. 1998. Viability of Nezara viridula (L.) eggs for parasitism by Trissolcus basalis (Woll.), under different storage techiniques in liquid Nitrogen. Anais da Sociedade Entomológica do Brasil 27: 101-107.

Douglas, A.E. 2003. The nutritional physiology of aphids. Advances in Insect Physiology 31: 73-140.

Duan,J.J., Teixeira, D., Huesing, J.E. \& Jiang, C. 2008. Assessing the risk to nontarget organisms from $B t$ corn resistant to corn rootworms (Coleoptera: Chrysomelidae): Tier-I testing with Orius insidiosus (Heteroptera: Anthocoridae). Environmenal Entomology 37: 838-844.

Fehr, W.R. \& Caviness, C.E. 1977. Stages of soybean development. Ames, University of Science and Technology, Special Report 80, 11 p.

Fernandes, F.S., Ramalho, F.S., Junior, J.L., Malaquias, J.B., Nascimento, A.R.B., Silva, C.A.D. \& Zanuncio, J.C. 2012. Within-plant distribution of cotton aphids, Aphis gossypii Glover (Hemiptera: Aphididae), in $B t$ and non- $B t$ cotton fields. Bulletin of Entomological Research 102: $79-87$.

Frizzas, M.R. \& Oliveira, C.M. 2006. Plantas transgênicas resistentes a insetos e organismos não-alvo: predadores, parasitoides e polinizadores. Universitas: Ciências da Saúde 4: 63-82.

Gamundi, J.C. \& Sosa, M.A. 2008. Caracterización de daños de chinches en soja y criterios para la tomada de decisiones de manejo, p. 29148. In: Trumper, E.V. \& Edelstein, J.D. (eds.). Chinches fitófagas en soja. Revisión y avances em el estudio de su ecología y manejo. Manfredi, Ediciones INTA, $190 \mathrm{p}$.

Gonzáles-Nuñez, M., Ortego, F. \& Castañera, P. 2000. Susceptibility of Spanish populations of the corn borers Sesamia nonagrioides (Lepidoptera: Noctuidae) and Ostrinia nubilalis (Lepidoptera: Crambidae) to a Bacillus thuringiensis endotoxin. Journal of Economic Entomology 93: 459-463.

Gouse, M., Pray, C. \& Schimmelpfenning, D. 2004. The distribution of benefits from $B t$ cotton adoption in South Africa. AgBioForum 7: 187-194.

Homrich, M.S., Passaglia, L.M.P., Pereira, J.F., Bertagnolli, P.F., Salvadori, J.R., Nicolau, M., Kaltchuk-Santos, E., Alves, L.B. \& BodaneseZanettini, M.H. 2008. Agronomic performance, chromosomal stability and resistance to velvetbean caterpillar of transgenic soybean expressing crylAc gene. Pesquisa Agropececuária Brasileira 43: 801-807.

Kouser, S. \& Qaim, M. 2011. Impact of Bt cotton on pesticide poisoning in smallholder agriculture: A panel data analysis. Ecological Economics 70: 2105-2113.

Larsson, M.C. \& Svensson, G.P. 2004. Methods in insect sensory ecology, p. 25-55. In: Christensen, T.A. (ed.). Methods in insect sensory neuroscience. Boca Raton, CRC Press, 464 p.

Laumann, R.A., Aquino, M.F., Moraes, M.C., Pareja, M. \& Borges, M. 2009. Response of the egg parasitoids Trissolcus basalis and Telenomus podisi to compounds from defensive secretions of stink bugs. Journal of Chemical Ecology 35: 8-19.

Li, G., Feng, H., McNeil, J.N., Liu, B., Chen, P. \& Qiu, F. 2011. Impacts of transgenic Bt cotton on a non-target pest, Apolygus lucorum (MeyerDür) (Hemiptera: Miridae), in northern China. Crop Protection 30: 1573-1578.

Loguercio, L.L., Santos, C.G., Barreto, M.R., Guimarães, C.T. \& Paiva, E. 2001. Association of PCR and feeding bioassays as a large-scale method to screen 
tropical Bacillus thuringiensis isolates for a cry constitution with higher insecticidal effect against Spodoptera frugiperda (Lepidoptera: Noctuidae) larvae. Letters in Applied Microbiology 32: 362-367.

Lopes, A.N.S., Diniz, I.R., Moraes, M.C.B., Borges, M. \& Lauman, R.A. 2012. Defesas induzidas por herbivoria e interações específicas no sistema tritrófico soja-percevejos-parasitoides de ovos. Pesquisa Agropecuária Brasileira 47: 875-878.

Lu, Y., Wu, K., Jiang, Y., Xia, B., Li, P., Feng, H., Wychhuys, K.A.G. \& Guo, Y. 2010. Mirid bug outbreaks in multiple crops correlated with wide-scale adoption of $B t$ cotton in China. Science 328: 1151-1154.

Orr, D.B. \& Landis, D.A. 1997. Oviposition of European corn borer (Lepidoptera: Pyralidae) and impact of natural enemy populations in transgenic versus isogenic corn. Jounal of Economic Entomology 90: 905-909.

Pacheco, D.J.P. \& Corrêa-Ferreira, B.S. 2000. Parasitismo de Telenomus podisi Ashmead (Hymenoptera: Scelionidae) em populações de percevejos pragas da soja. Anais da Sociedade Entomológica do Brasil 29: 295-302.

Panizzi, A.R. \& Parra, J.R.P. 1991. Ecologia nutricional dos insetos e suas implicações no manejo de pragas. São Paulo, Editora Manole, 359 p.

Panizzi, A.R. \& Rossini, M.C. 1987. Impacto de várias leguminosas na biologia de ninfas de Nezara viridula (Hemiptera: Pentatomidae). Revista Brasileira de Biologia 47: 507-512

Pray, C.E., Huang, J., Hu, R. \& Rozelle, S. 2002. Five years of Bt cotton in China - the benefits continue. The Plant Jounal: for cell and molecular biology 31: 423-430.

Roese, A.D., Romani, R.D., Furlanetto, C., Tangarlin, J.R. \& Portz, R.L. 2001. Levantamento de doenças na cultura da soja, Glycine max (L.) Merrill, em municípios da região Oeste do Estado do Paraná. Acta Scientiarum 23: 1293-1297.

Romeis, J. \& Meissle, M. 2011. Non-Target risk assessesment of Bt crops - Cry protein uptake by aphids. Journal of Applied Entomology 135: 1-6.

Saluso, A., Xavier, L., Silva, F.A.C. \& Panizzi, A.R. 2011. An invasive pentatomid pest in Argentina: Neotropical stink bug, Euschistus heros (F.) (Hemiptera: Pentatomidae). Neotropical Entomology 40: 704-705.

Sanvido, O., Romeis, J. \& Bigler, F. 2009. An approach for post-market monitoring of potential environmental effects of Bt-maize expressing Cry $1 \mathrm{Ab}$ on natural enemies. Journal of Applied Entomology 133: 236-248.

Sas Institute. 2001. Sas user's guide: statistics, version 6e. Cary, 201p.

Shapiro, S.S. \& Wilk, M.B. 1965. An analysis of variance test for normality. Biometrika 52: 591-611.

Sharma, H.C. \& Ortiz, R. 2000. Transgenics, pest management, and the environment. Current Science 79: 421-437.
Silva, C.C., Moraes, M.C.B., Lauman, R.A. \& Borges, M. 2006. Sensory response of the egg parasitoid Telenomus podisi to stimuli from the bug Euschistus heros. Pesquisa Agropecuária Brasileira 41: 1093-1098.

Siqueira, F. 2007. Adição de frutos de Ligustrum lucidum ait. (Oleaceae) em dieta artificial seca para a criação do percevejo marrom Euschistus heros (f.) (Heteroptera: Pentatomidae). M.Sc. thesis. Curitiba, Universidade Federal do Paraná, 58 p.

Sisterson, M.S., Biggs, R.W., Manhardt, N.M., Carrière, Y., Dennehy, T.J. \& Tabashnik, B.E. 2007. Effects of transgenic Bt cotton on insecticide use and abundance of two generalist predators. Entomologia Experimentalis et Applicata 124: 305-311.

Sosa-Gómes, D.R. \& Silva, J.J. 2010. Neotropical brown stink bug (Euschistus heros) resistance to methamidophos in Paraná, Brazil. Pesquisa Agropecuária Brasileira 45: 767-769.

Vinson, S.B. 1997. Comportamento da seleção hospedeira de parasitoides de ovos, com ênfase na família Trichogrammatidae, p. 67-120. In: Parra, J.R.P., \& Zucchi, R.A. (eds.). Trichogramma e o Controle Biológico Aplicado. Piracicaba, FEALQ, 324 p.

Wackers, F.L. \& Lewis, W.J. 1994. Olfactory and visual learning and their combined influence on host site location by the parasitoid Microplitis croceipes (Cresson). Biological Control 4: 105-112.

Williams, M.R. 2006. Cotton insect losses 2005, p. 1151-1204. In: Proceedings of the Beltwide Cotton Conferences, National Cotton Council, Memphis.

Wilson, L., Hickman, M. \& Deutscher, S. 2006. Research update on IPM and secondary pests, p. 249-258. In: Proceedings of the 13th Australian Cotton Research Conference, Broadbeach, Queensland, Australia.

Wu, K. 2001. IPM in cotton, p. 218-224. In: Jia, S. (ed.). Transgenic cotton. Beijing, Science Press.

Wu, K., Mu, W., Liang, G. \& Gou, Y. 2005. Regional reversion of insecticide resistance in Helicoverpa armigera (Lepidoptera: Noctuidae) is associated with the use of $B t$ cotton in northern China. Pest Management Science 61: 491-498.

Xia, J.Y., van der Werf, W. \& Rabbinge, R. 1999. Influence of temperature on bionomics of cotton aphid, Aphis gossypii, on cotton. Entomologia Experimentalis et Applicata 90: 25-35.

Yan, W.-D., Shi, W.-M., Li, B.-H. \& Zhang, M. 2007. Overexpression of a foreign $B t$ gene in cotton affects the low-molecular-weight components in root exudates. Pedosphere 17: 324-330.

Yu, H.-L., Yun, H.-L. \& Kong-Ming.,W. 2011. Risk assessment and ecological effects of transgenic Bacillus thuringiensis crops on nontarget organisms. Journal of Integrative Plant Biology 53: 520-538.

Received 14 February 2014; accepted 2 July 2014

Associate Editor: Daniel R. Sosa-Gómez 